\title{
CLINCHING AS A NON-STANDARD METHOD FOR JOINING MATERIALS OF DISSIMILAR PROPERTIES
}

\begin{abstract}
The automotive industry is currently working to accommodate the conflicting requirements of both environmental legislation and customer demands for greater performance and more luxury and safety features, by developing a light-weight and therefore essentially, energy-efficient vehicle. To satisfy these demands, various materials are used in car body production. But it is not always possible to join these materials by common joining method such as resistance spot welding; therefore clinching seems to be possible alternative. The paper dealt with the evaluation of properties of joints made by clinching. The sheets made of the high-strength low-alloy steel H220PD $\left(a_{0}=0.8 \mathrm{~mm}\right)$, advanced high strength steel RA-K $40 / 70+Z 100 \mathrm{MBO}\left(a_{0}=0.77 \mathrm{~mm}\right)$ and the drawing grade steel DX51D+Z $\left(a_{0}=\right.$ $=0.9 \mathrm{~mm}$ ) were used for the experiments. The following tests were performed to evaluate the properties of the clinched joints: tensile test and a metallographical analysis.
\end{abstract}

Keywords: clinching, resistance spot welding, metallographic analysis, automotive industry

\section{Introduction}

One of the possibilities of decreasing the car weight and consequently lowering the fuel consumption is using various combinations of materials, such as combination of conventional deep-drawn steel sheet and high-strength steel sheet. In the areas, where high passive safety is needed, high-strength steels such as TRIP can be used (Fig. 1). The usage of such steels can significantly reduce the car weight [1].

The increasing use of coated, lightweight and high-strength materials has led the automotive industry to re-examine traditional methods of component assembly [2]. For example, direct welding of dissimilar sheet metals has proven to be difficult or impossible; thus, alternative joining techniques, such as mechanical fastening systems, have attracted increasing interest and applications in recent years. Mechanical fastening encompasses a broad range of methods, from 
threaded fasteners to different forms of rivets and mechanical interlocking methods [3].

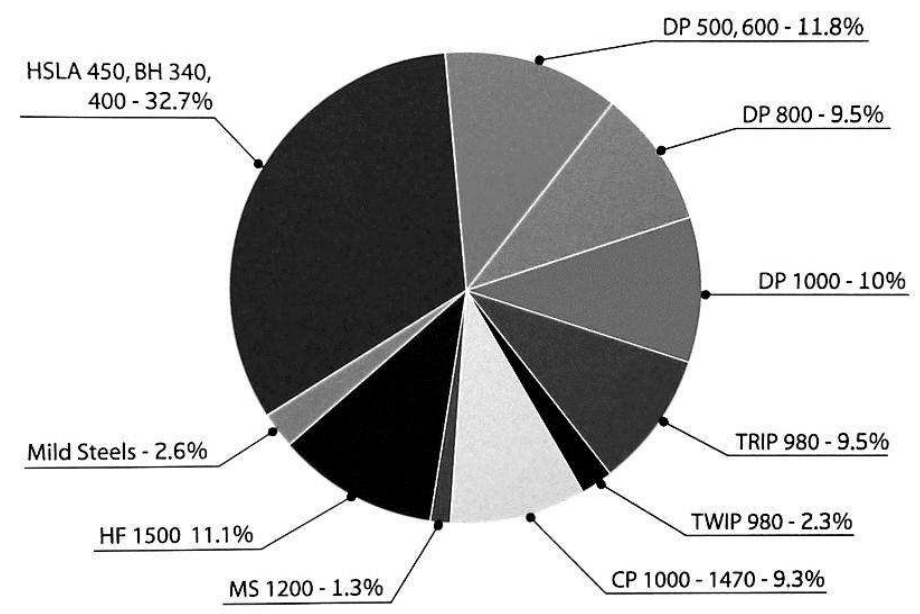

Fig. 1. Various materials used in production of car body (Fiat)

Clinching technology is one of the mechanical fastening methods. Although clinching has been known for many years, only in recent years increased industrial interest in clinching is noticed since the technique was successfully applied to complement or even replace other joining techniques such as, for example, spot welding [4-6]. Clinching does not use any kind of appending joining components. Only a die and a punch are used to press the sheet components to finish the whole joining process. The clinching process is a combination of drawing and forming that locks together sheets metal layers. The blanks are plastically deformed and the shape of the tools remains theoretically unchanged during the clinching processes [7]. The punch is movable, whereas the fixture and the die are fixed during the process (Fig. 2) [8]. The punch force needed for the joining process depends on the thickness and the strength of the materials to be joined, the size of the tools and friction coefficient [6]. The clinching technique has become popular alternative to conventional resistance spot welding due to the growing use of alternative materials, which are difficult or impossible to weld, for example in automotive industry [1]. This technique can be utilized when joining galvanized, painted or organically plated materials; therefore it is successfully used in car-body production (Fig. 3). 

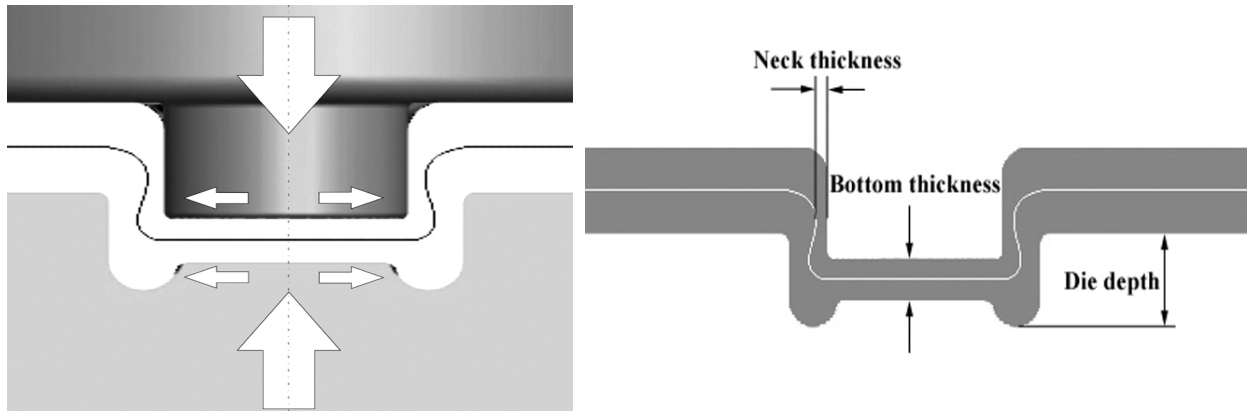

Fig. 2. Process of clinching

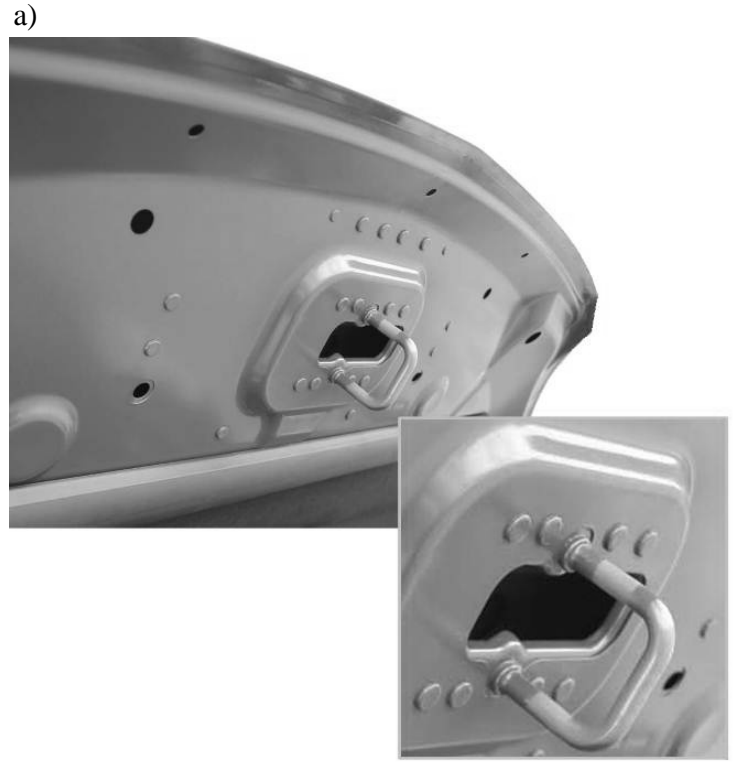

b)

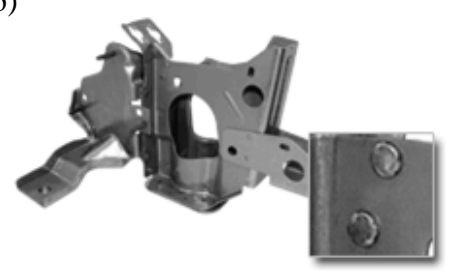

c)

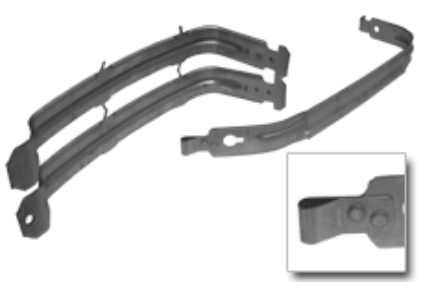

d)

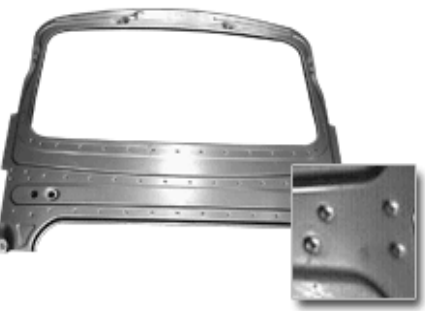

Fig. 3. The examples of using the clinching method: a) car hood, b) brake pedal bracket, c) gas tank straps, d) roof bow

\section{Material and experiment}

The following steel sheets were used for the experiments: high-strength low-alloy steel H220PD with the thickness of $0.8 \mathrm{~mm}$, advanced high strength 
steel RA-K 40/70 with the thickness of $0.77 \mathrm{~mm}$ and drawing grade steel DX51D+Z with the thickness of $0.9 \mathrm{~mm}$. Their basic mechanical properties and chemical composition are shown in Table 1 and 2. Mechanical properties of DX51D+Z steel were specified by a producer. The surfaces of all sheets are uniform and their uniformity features good protection capabilities. Moreover, the galvanized coating is lead-free, providing with good anti-corrosion features and preventing galvanic layer fracturing when straining [9].

Table 1. Basic mechanical properties of used steels

\begin{tabular}{|c|c|c|c|c|}
\hline Material & $\boldsymbol{R}_{\boldsymbol{p 0 . 2}}[\mathbf{M P a}]$ & $\boldsymbol{R}_{\boldsymbol{m}}[\mathbf{M P a}]$ & $\boldsymbol{A}_{\mathbf{8 0}}[\boldsymbol{\%}]$ & $\mathbf{n}$ \\
\hline H220PD & 238 & 382 & 36 & 0.228 \\
\hline RA-K40/70 & 450 & 766 & 26 & 0.278 \\
\hline DX51D+Z & 180 & 335 & 25 & 0.190 \\
\hline
\end{tabular}

Table 2. Chemical composition [wt \%] of used steel sheets

\begin{tabular}{|c|c|c|c|c|c|c|c|c|c|}
\hline Material & C & Mn & $\mathbf{S i}$ & $\mathbf{P}$ & $\mathbf{S}$ & Al & $\mathbf{C u}$ & $\mathbf{N i}$ & $\mathrm{Cr}$ \\
\hline $\mathrm{H} 220 \mathrm{PD}$ & 0.06 & 0.7 & 0.5 & 0.080 & 0.025 & 0.020 & 0.011 & 0.017 & 0.310 \\
\hline RA-K40/70 & 0.204 & 1.683 & 0.198 & 0.018 & 0.003 & 1.731 & 0.028 & 0.018 & 0.055 \\
\hline DX51D & 0.064 & 0.178 & 0.007 & 0.016 & 0.002 & 0.120 & 0.041 & 0.02 & 0.023 \\
\hline Material & $\mathbf{T i}$ & V & $\mathrm{Nb}$ & Mo & $\mathbf{Z r}$ & & & & \\
\hline H220PD & 0.037 & 0.002 & 0.026 & 0.005 & 0.001 & & & & \\
\hline RA-K40/70 & 0.009 & 0.004 & 0.004 & 0.008 & 0.007 & & & & \\
\hline
\end{tabular}

According to the orientation of punch and die to the position of upper and lower joined material, following combinations of steel sheets for press joining were used:

- H220PD $(a 0=0.80 \mathrm{~mm})$ and RA-K $(a 0=0.77 \mathrm{~mm})^{*}$, marked as samples A,

- RA-K $(a 0=0.77 \mathrm{~mm})$ and H220PD $(a 0=0.80 \mathrm{~mm})^{*}$, marked as samples B,

- H220PD $(a 0=0.80 \mathrm{~mm})$ and H220PD $(a 0=0.80 \mathrm{~mm})$, marked as samples C,

- RA-K $(a 0=0.77 \mathrm{~mm})$ and DX51D $(a 0=0.90 \mathrm{~mm})^{*}$, marked as samples D,

- DX51D $(a 0=0.90 \mathrm{~mm})$ and RA-K $(a 0=0.77 \mathrm{~mm})^{*}$, marked as samples E.

* sheet on the die side of press joining tool 
Clinching was performed on the tension machine ZD 40 made by Werkstoffprüfmaschinen Leipzig Company with the loading range of $40 \mathrm{kN}$. The force needed for joining was $30 \mathrm{kN}$. The real strength of the joints can only be defined by the use of destructive testing. The tension test according to STN 051122 standard (tension test of spot welded joints) is the most popular test for evaluation of carrying capacities of the spot welded joints. Thus, maximum cutting force was determined as a priority strength index. The samples with dimensions of $40 \times 90 \mathrm{~mm}$ and $30 \mathrm{~mm}$ lapping according to STN 051122 standard were used for the experiments (Fig. 4). Six samples were prepared for every combination of sheets. The surfaces joined materials have not been cleaned before clinching. The tensile test was carried out on the metal strength testing machine TIRAtest 2300 produced by VEB TIW Rauenstein, with the loading speed of $8 \mathrm{~mm} / \mathrm{min}$. The joining process was conducted in the laboratory using own tool. The tools (Fig. 5) used in experimental analysis of clinched joints (punch and die with specified impression) were constant.

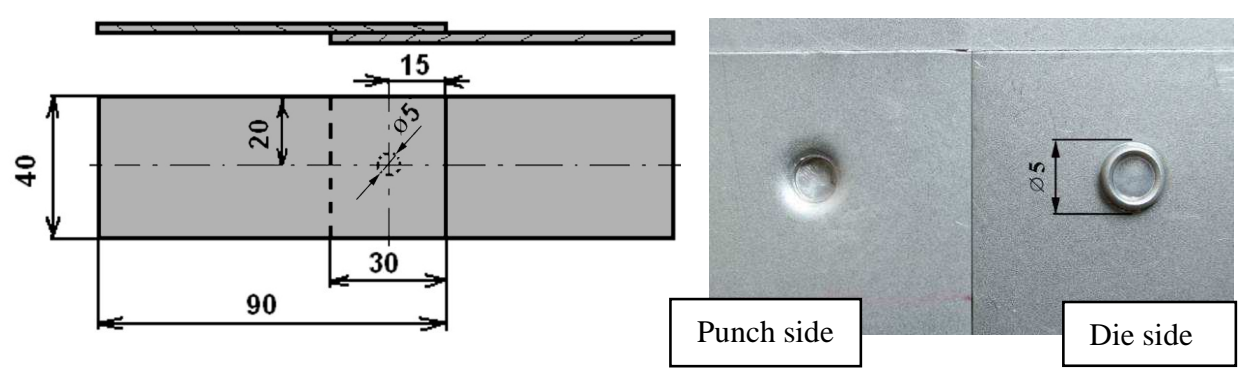

Fig. 4. Dimensions of samples for the tensile test
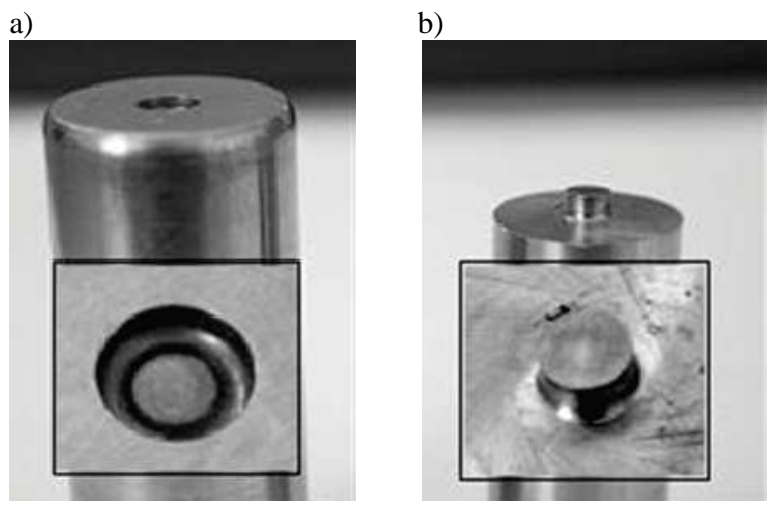

Fig. 5. Clinching tools: a) die, b) punch 
Further tests for quality evaluation of clinched joints included the metallographic analysis. The results of carrying capacities of clinched joints were compared with the carrying capacities of resistance spot welded joints.

\section{Results}

The measured values of carrying capacities of clinched joints after tensile test in comparison with the measured values of carrying capacities of resistance spot welded joints are shown in Table 3 . The resistance spot welded joints were made with the optimized values of welding parameters $[1,10]$. The resistance spot welds of all observed samples reached higher values of carrying capacities in comparison with clinched joints. On average, the clinched joints reached about $13 \%$ (samples A), 18\% (samples C) and 21\% (samples E) of carrying capacities of resistance spot welds.

Table 3. Measured values of carrying capacities $F_{\max }$

\begin{tabular}{|c|c|c|c|c|c|c|}
\hline \multirow{3}{*}{ Sample no } & \multicolumn{6}{|c|}{ Carrying capacity $\boldsymbol{F}_{\max }[\mathbf{N}]$} \\
\cline { 2 - 7 } & \multicolumn{2}{|c|}{ samples A } & \multicolumn{2}{c|}{ samples C } & \multicolumn{2}{c|}{ samples E } \\
\cline { 2 - 7 } & CJ & RSW & CJ & RSW & CJ & RSW \\
\hline 1 & 939 & 7310 & 980 & 5305 & 1087 & 7420 \\
\hline 2 & 985 & 7641 & 1008 & 5290 & 1584 & 7644 \\
\hline 3 & 1016 & 7680 & 956 & 5072 & 1334 & 7710 \\
\hline 4 & 1080 & 7172 & 924 & 5260 & 1834 & 7417 \\
\hline 5 & 1093 & 7417 & 973 & 5238 & 1973 & 7565 \\
\hline 6 & 937 & 7581 & 978 & 5177 & 1658 & 7513 \\
\hline
\end{tabular}

CJ - clinched joints, RSW - resistance spot welded joints

The carrying capacities of samples B and samples D were not measured, because the clinched joints were not successfully created. Joining failed during clinching process. The upper sheets of both samples RA-K 40/70 steel were cut off in the place of the joint and then pressed to the lower sheet (Fig. 6a).

Successfully created clinched joints failed during tensile test at the neck of the joint as shown in Fig. 6b. There is insufficient material in the neck of the joint, and loading will result in failure in the neck. Excessive elongation in that region of the joint neck causes crack formation. The failures occurred in the critical area of clinched joints. The critical area is the place of the most significant thinning of the joined materials. The average value of carrying capacities of samples A was $1008 \mathrm{~N}$. The cracks in the RA-K steel were observed on the die side (Fig. 7), which could possibly have a negative effect - on dynamic load or corrosion resistance. The values of carrying capacity of samples A are similar to 
the values measured in clinched joints of the common drawing grade steel sheets, as was published in [7].

a)

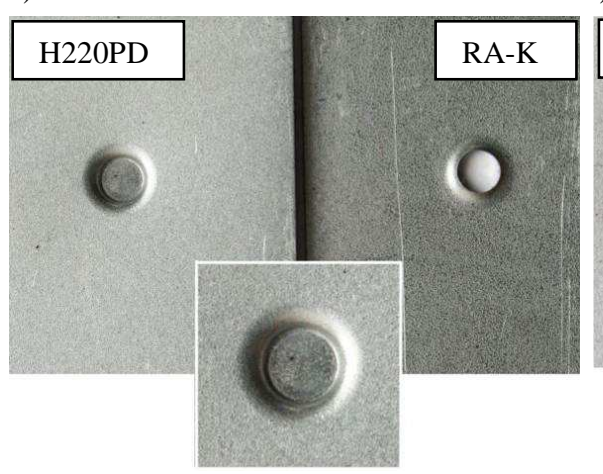

b)

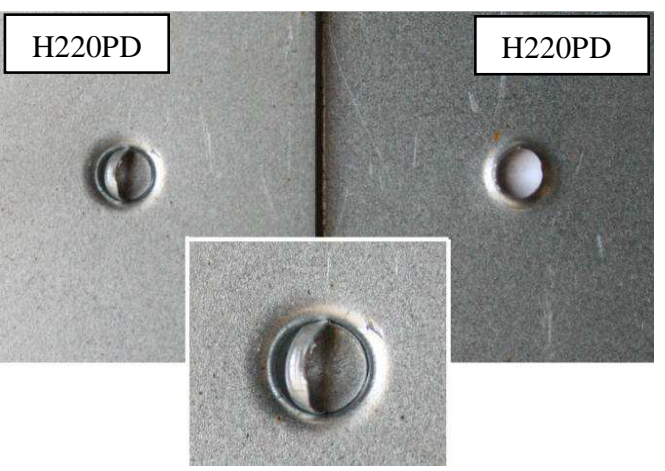

Fig. 6. Failures of clinched joints: a) sample D, b) sample C

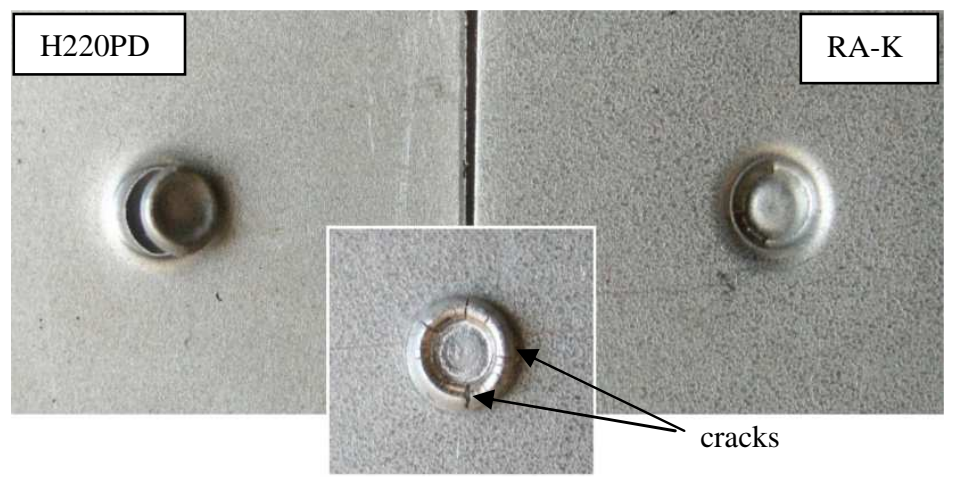

Fig. 7. Failures of clinched joint of sample A

The average value of carrying capacity of samples C was 970 N. No cracks occurred in the place of the joint from the side of the die. The carrying capacity values of samples $\mathrm{C}$ are similar to the values measured in clinched joints of common drawing grade steel sheets. The average value of carrying capacity of samples E was 1578 N. Cracks in the RA-K steel on the die side were observed, similar to those in sample A. The measured values of carrying capacity of samples $\mathrm{E}$ are higher than those of samples $\mathrm{A}$ and $\mathrm{C}$, which is probably caused by the thicker material of the upper sheet in the joint $-0.9 \mathrm{~mm}$. Figure 8 shows the obtained load-displacement curves of clinched joints of all successfully made samples $-\mathrm{A}, \mathrm{C}$, and $\mathrm{E}$. The curve shapes of samples $\mathrm{A}$ and $\mathrm{C}$ are very similar as 
well as the values of their carrying capacities. The metallographic analysis confirmed that the area with the most significant thinning in the joint is its critical area (Fig. 9). Failures occurred in such areas during tensile tests of samples A, C and $\mathrm{E}$, and during the clinching process in samples $\mathrm{B}$ and $\mathrm{D}$. The metallographic analysis confirmed the occurrence of cracks in the RA-K steel on the die side of the joints in the round part (Fig. 10).

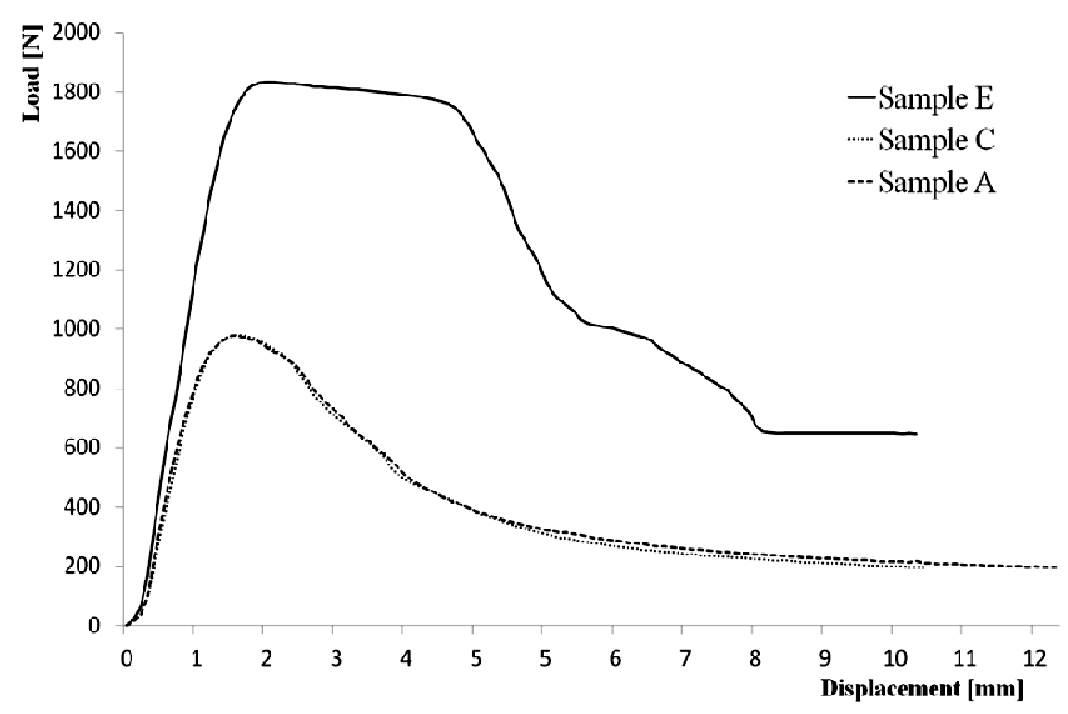

Fig. 8. Load-displacement curves of clinched joints

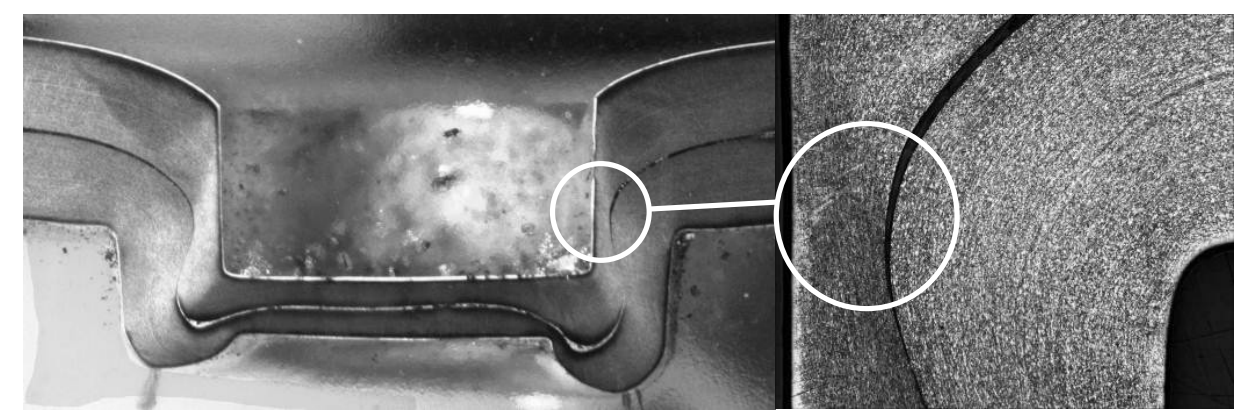

Fig. 9. The critical area of clinched joint 

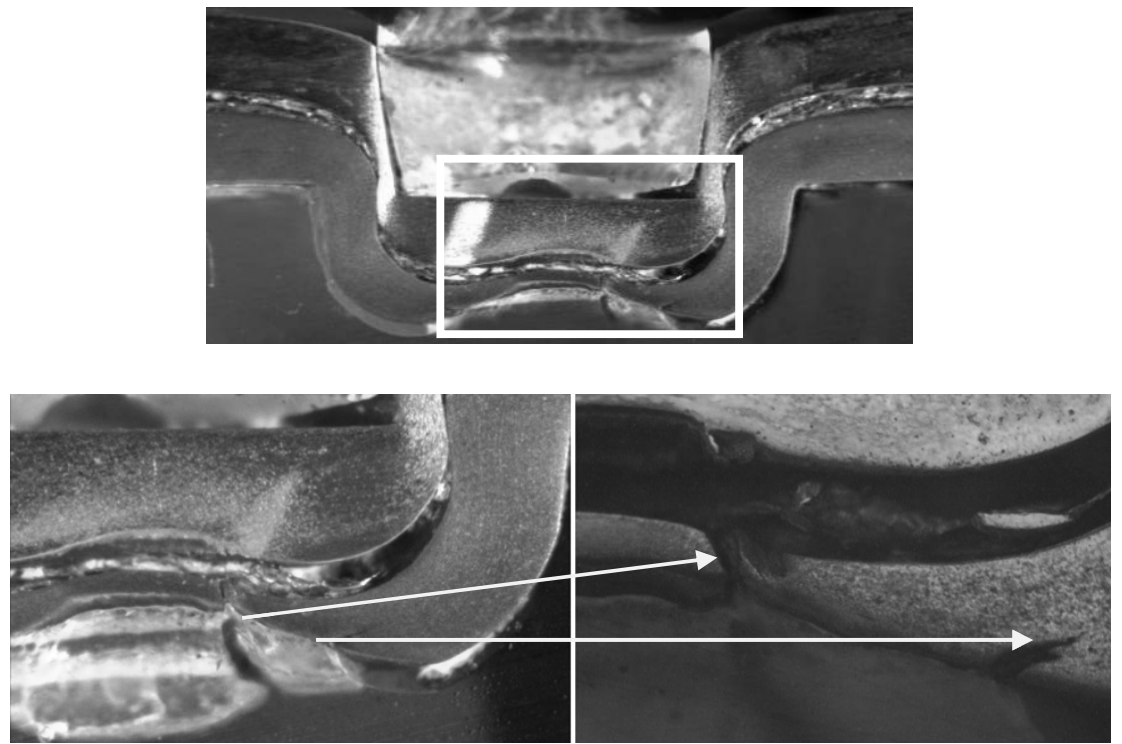

Fig. 10. The cracks in RA-K steel on the side of die - sample A

\section{Conclusions}

Various materials are used in car body production. Numerous issues arise not only in their formation but also in joining. It is not always possible to use conventional joining methods such as resistance spot welding; therefore clinching method seems to be possible alternative. The paper evaluated the properties of joints made by clinching method focusing on the high-strength low-alloy steel H220PD, advanced high strength steel RA-K 40/70+Z100MBO and the drawing grade steel DX51D+Z $\left(a_{0}=0.9 \mathrm{~mm}\right)$.

Orientation of joined materials regarding the position of the punch and die has a significant effect on the carrying capacities of the joints. The material combinations of RA-K 40/70 with H220PD as well as RA-K 40/70 with DX51D, where RA-K steel is situated towards the punch, are not suitable for clinching with observed geometry of tools (with specified punch and die), because the joints were not created. The failures already occur during the clinching process in the critical areas of joints. The same material combinations where RA-K steel is oriented towards the die proved to be unsuitable for joining by clinching, even though joints were created, because occurring of cracks in RA-K steel. The cracks could negatively affect the joints (especially during dynamic load) even decrease the corrosion resistance of the joints.

Combination of H220PD materials was the only combination that proved to be suitable for joining with the tools of observed geometry. The carrying capaci- 
ties of these samples were sufficient and the metallographical analysis confirmed no occurrence of cracks or failures in the area of clinched joints.

Next study should be focused on the possibility to make successful clinched joints of material combination of RA-K with H220PD and RA-K with DX51D with the optimized tool geometry for every material combination or focused on the clinching when joined materials are heated before clinching process.

\section{References}

[1] Spišák E., Kaščák L., Viňáš J.: Research into properties of joints of combined materials made by resistance spot welding, Chemické Listy, 105 (2011), 488-490.

[2] Kaščák L., Spišák E., Mucha J.: Joining of steel sheets for automotive industry using press joining method, Zeszyty Naukowe Politechniki Rzeszowskiej, 273, Mechanika, 80 (2010), 121-126.

[3] Abe Y., Kato T., Mori K.: Joinability of aluminium alloy and mild steel sheets by self-piercing rivet, J. Mat. Proc. Technol., 177 (2006), 417-421.

[4] Nong N. et.al.: Feipeg: Research on press joining technology for automotive metallic sheets, J. Mat. Proc. Technol., 137 (2003), 159-163.

[5] Atzeni E., Ippolito R., Settineri L.: Experimental and numerical appraisal of selfpiercing riveting, CIRP Annals, 582 (2009), 17-20.

[6] Spišák E., Kašćák L.: Joining car body steel sheets using the clinching method, Acta Mech. Slovaca, 15 (2011), 28-34.

[7] Varis J.P.: The suitability of clinching as a joining method for high-strength structural steel, J. Mat. Proc. Technol., 132 (2003), 242-249.

[8] Paula de A.A. et.al.: Finite element simulations of the clinch joining of metallic sheets, J. Mat. Proc. Technol., 182 (2007), 352-357.

[9] Vaško A., Belan J.: Applications of methods of quantitative metallography in materials engineering, Int. J. Applied Mech. Engn., 15 (2010), 405-410.

[10] Kaščák L'., Viňáš J.: Influence of welding parameters of resistance spot welding on the quality of welded joints, Zeszyty Naukowe Politechniki Rzeszowskiej, 273, Mechanika, 80 (2010), 127-134.

This work was supported by the Slovak Research and Development Agency under the contract No APVV-0682-11.

\section{KLINCZOWANIE JAKO NIESTANDARDOWA METODA LĄCZENIA MATERIAŁÓW O ODMIENNYCH WŁAŚCIWOŚCIACH}

Streszczenie

Przemysł samochodowy jest obecnie skupiony na spełnianiu sprzecznych wymagań przepisów ochrony środowiska oraz potrzeb klientów w zakresie poprawy komfortu i cech bezpieczeństwa przez rozwijanie produkcji samochodów o lekkiej konstrukcji, a zatem energooszczędnych. 
Spełnienie tych wymagań jest możliwe przez wprowadzenie różnych materiałów do produkcji karoserii samochodowych. Łączenie tych materiałów za pomocą powszechnie stosowanej metody zgrzewania oporowego nie jest zawsze możliwe, dlatego klinczowanie wydaje się być metodą alternatywną. Artykuł przedstawia ocenę właściwości połączeń wykonanych metodą klinczowania. W badaniach eksperymentalnych wykorzystano blachy ze stali wysokowytrzymałej niskowęglowej H220PD ( $a_{0}=0,8 \mathrm{~mm}$ ), wielofazową stal wysokowytrzymałą RA-K 40/70+Z100MBO $\left(a_{0}=0,77 \mathrm{~mm}\right)$ i stal przeznaczoną do tłoczenia DX51D+Z $\left(a_{0}=0,9 \mathrm{~mm}\right)$. Właściwości połączeń klinczowych oceniano podczas próby rozciągania i analizy metalograficznej.

Słowa kluczowe: przemysł samochodowy, klinczowanie, zgrzewanie oporowe, badania metalograficzne

DOI: $10.7862 / \mathrm{rm} .2012 .3$ 